FOKUS

Jurnal Kajian Keislaman

dan Kemasyarakatan
Institut Agama Islam Negeri (IAIN) Curup, Indonesia

ISSN 2548-334X (p); 2548-3358 (e)

volume 6, number 2, 2021 | page: 207-230

DOI: http://doi.org/10.29240/jf.v6i2.2574

\title{
Rekam Jejak Kegagalan Turki Menjadi Anggota Uni Eropa
}

\author{
${ }^{1}$ Hendra Maujana Saragih, ${ }^{2}$ Suhayatmi, ${ }^{3}$ Annisa Fatehha Dwi Stelwar, \\ 4 Muhammad Zulham \\ 1 Universitas Nasional, Jakarta, Indonesia \\ ${ }^{2}$ Universitas Nasional, Jakarta, Indonesia \\ ${ }^{3}$ Universitas Nasional, Jakarta, Indonesia \\ ${ }^{4}$ Universitas Pertahanan, Bogor, Indonesia \\ suhayatmi_9@gmail.com,hendramaujana@gmail.com (correspondence), \\ nissastelwar@gmail.com, mzulham712@gmail.com
}

\begin{abstract}
This paper describes the various efforts achieved by Turkey to be accepted as a member of the European Union. Turkey has applied for full EU membership officially since 34 years, or to be precise on April 14, 1987 ago. Various preconditions put forward by the European Union have tried to fulfill Turkey, which is hampered by issues of law enforcement, human rights, democracy, to claims of illegal immigrants as well as from the Middle East, especially Syria. Strongly convince Turkey to be able to join the European Union which was founded by several factors, including a very large economic area and also a very large military power. The method used in conducting research on the track record of Turkey's failure to become a member of the European Union is the qualitative method. This method can describe some of the obstacles faced by Turkey to become a member of the European Union. The conclusion from the results of this study shows that the organization is the single most powerful and integrated regional integration in the world and has not received Turkey's participation.
\end{abstract}

Keywords: Turkey, European Union, Europe, Democracy, Human Rights

Abstrak. Karya tulis ini menggambarkan berbagai upaya yang ditempuh Turki agar dapat diterima menjadi anggota Uni Eropa. Turki telah mengajukan permohonan keanggota penuh Uni Eropa secara resmi sejak 34 tahun atau tepatnya pada 14 April 1987 silam. Berbagai prasyarat yang diajukan Uni Eropa telah berusaha dipenuhi Turki yang selama ini terganjal oleh isu penegakan hukum, HAM, demokrasi, stabilitas ekonomi hingga hingga klaim sebagai pintu masuk imigran ilegal serta terorisme dari Timur Tengah, khususnya Suriah. Keinginan kuat Turki untuk dapat bergabung kedalam Uni Eropa didasari oleh beberapa faktor, diantaranya adalah memiliki kawasan ekonomi yang sangat 
luas dan juga kekuatan militer yang sangat besar. Adapun metode yang digunakan dalam melakukan penelitian mengenai rekam jejak kegagalan Turki untuk menjadi anggota Uni Eropa yaitu metode kualitatif. Metode ini dapat mendeskripsikan beberapa hambatan-hambatan yang dihadapi Turki untuk menjadi anggota Uni Eropa. Kesimpulan dari hasil penelitian ini menunjukkan organisasi supranasional yang merupakan satu-satunya integrasi regional paling kuat dan terintegrasi di dunia tersebut belum bersedia menerima keanggotaan Turki.

Kata Kunci: Turki, Uni Eropa, Eropa, Demokrasi, Hak Asasi Manusia

\section{Pendahuluan}

Sebagai negara yang terletak di antara dua benua yaitu Eropa dan Asia dengan wilayahnya yang terbentang dari semenanjung Anatolia di Asia Barat Daya dan daerah Balkan di Eropa, Turki memiliki posisi yang sangat strategis mewariskan berbagai macam kisah perkembangan peradaban dunia antara Barat dan Timur yang tidak pernah lekang oleh waktu. Republik Turki 97\% wilayahnya berada di benua Asia, sedangkan 3\% wilayah lainnya berada di benua Eropa. Adapun batas negara Turki di sebelah selatan dan utara yaitu berbatasan dengan Laut Mediterania dan Laut Hitam. Di sebelah Timur dan Timur laut berbatasan dengan Armenia, Iran, Azerbaijan, dan Georgia. Sedangkan, di sebelah barat laut dan tenggara wilayah Turki berbatasan dengan Yunani, Bulgaria, Irak dan Suriah. ${ }^{1}$

Meskipun wilayah Turki hampir sebagian besar terpusat di benua Asia, akan tetapi Turki lebih senang apabila diidentikkan sebagai bagian dari komunitas Eropa daripada Asia. Hal ini dapat terlihat sejak masa kepemimpinan Presiden pertama Turki yaitu Mustafa Kemal Atatürk pasca runtuhnya Imperium Turki Usmani pada tahun 1923 yang semakin intensif untuk membangun nilai-nilai Barat di negara Turki. Salah satu upayanya yaitu dengan melakukan transformasi terhadap sistem pemerintahan Turki dari yang sebelumnya Konstitusi Islam menjadi Konstitusi pemerintah yang bersifat sekularisme, pluralis dan parlementer seiring dengan perkembangan politik negara Barat. ${ }^{2}$ Sejak transformasi tersebut, pemerintah Turki melakukan beberapa perubahan terkait dengan kebijakan-kebijakan dalam negerinya,

\footnotetext{
${ }^{1}$ Nations online, Turkey. n.d (artikel online), melalui link https://www.nationsonline.org/oneworld/turkey.htm diakses pada 25 Agustus 2021

2 George Lenczowski, Timur Tengah di kancah Dunia (Bandung: Sinarbaru Algesindo, 1993), 78-79; Robert D. Lee, Religions and Politics in the Middle East, "The Politics and Religion in Secularist Turkey (Colorado, USA: Westview press, 2010), 167 168.
} 
salah satunya yaitu dengan menerapkan Undang-undang Sipil (Court Civil) yang di mana dalam proses penerapannya pemerintah Turki berpedoman kepada kebijakan pemerintahan Swiss.

Tidak hanya kebijakan dalam negerinya saja, pemerintah Turki juga mengubah pola kebijakan luar negerinya sebagai upaya untuk membangun dan memperkuat nilai-nilai Barat di mata dunia internasional. Perubahan kebijakan yang dimaksud tersebut diantaranya yaitu dengan menjalin hubungan baik dengan Barat, seperti berpartisipasi menjadi keanggotaan NATO (North Atlantic Treaty Organization) pada tahun 1952 dan bergabung dengan PBB (Perserikatan Bangsa-Bangsa). Hasilnya seperti yang telah direncanakan bahwa keanggotaan serta kontribusi Turki di beberapa organisasi telah membawa Turki menjadi negara yang dinilai terbuka terhadap nilai-nilai Barat. Hal ini membuat Turki ingin menjalin hubungan kerja sama ekonomi dengan negara kawasan tetangganya, yaitu Eropa. Pada tanggal 31 July 1959, Turki pun mulai menjalin kemitraan perdagangan dengan Masyarakat Ekonomi Eropa. ${ }^{3}$

Kerja sama ini pun dilanjutkan dengan penandatanganan Perjanjian Asosiasi Ankara (Ankara Association Agreement) pada tanggal 12 September 1963 sebagai bentuk negoisasi perdagangan serta hubungan bilateral antara Turki dengan Masyarakat Ekonomi Eropa (EEC). ${ }^{4}$ Adapun ketentuan utama dari perjanjian ini yaitu sebagai komitmen Turki untuk membentuk serikat pabean yang akan diterapkan di setiap negara anggotanya. Di samping itu, kerja sama ini juga sebagai jalur awal Turki menuju aksesi keanggotaan Masyarakat Ekonomi Eropa.

Dan pada tahun 1987, secara resmi Turki mengajukan keanggotaannya pada EEC yakni organisasi yang merupakan cikal bakal Uni Eropa. Namun saat Eropa menyatu menjadi Masyarakat Ekonomi Eropa (CEE) dan berubah menjadi Uni Eropa, Turki selalu ditinggalkan, sementara negara-negara lainnya bisa diterima masuk Uni Eropa, seperti Rumania, Polandia, dan Siprus yang menjadi

${ }^{3}$ Ilham Ozturk dan Kamil Sertoglu, "Turkey and European Union Relations : Concept of the Custom Union," Pakistan Horizon, Vol. 56, No.3, 2003, melalui link https://mpra.ub.uni-muenchen.de/333/1/MPRA_paper_333. pdf; dan diakses pada 25 Agustus 2021

${ }^{4}$ History of Turkey-EU Relations 1959 - 2019, melalui website Republic of Turkey Ministry of Foreign Affairs Directorate for EU Affairs, tersedia melalui link https://www.ab.gov.tr/siteimages/birimler/kpb/chronology-_en-_1959_ocak2020.pdf, diakses pada 25 Agustus 2021. 
seteru Turki. ${ }^{5}$ Dalam hal ini, Uni Eropa telah bersedia untuk menjalin kemitraan khusus "privileged partnership" dengan Turki mengingat Turki sebagai mitra strategis utama Uni Eropa dalam isu-isu seperti migrasi, keamanan, kontraterorisme dan ekonomi. Akan tetapi Turki menolak status tersebut dan menginginkan status keanggotaan penuh. Sebagai tanggapan tersebut, Dewan Eropa mengajukan Kriteria Kopenhagen (Copenhagen Criteria) sebagai persyaratan untuk menjadi keanggotaan penuh Uni Eropa. Kriteria Kopenhagen sendiri merupakan hasil perjanjian European Community yang telah diratifikasi di Kopenhagen, Denmark pada tahun 1993. Adapun kriterianya meliputi stabilitas institusional sebagai jaminan akan demokrasi, supremasi hukum, menjaga dan menjunjung tinggi nilai-nilai Hak Asasi Manusia serta perlindungan terhadap minoritas. Namun dalam perkembangannya, proses negosiasi antara Turki dengan Uni Eropa terkait dengan status keanggotaan Turki di organisasi supranasional tersebut tidak berjalan lancar bahkan hingga kini ditolak. Hal ini dikarenakan sebagian besar negara anggota tidak menyetujuinya, terutama negara Jerman dan Prancis. Sentimen kedua negara ini terhadap Turki semakin kuat dirasakan sehingga dapat mempengaruhi putusan Uni Eropa yang secara resmi memutuskan untuk tidak menindaklanjuti proses keanggotaan penuh Turki.

Uni Eropa sendiri merupakan salah satu organisasi supranasional terbesar di dunia yang beranggotakan 27 negara di Eropa, setelah sebelumnya Inggris memilih untuk keluar pada 1 Februari 2020 lalu atau dikenal dengan istilah Brexit (British Exit). Meski demikian, hingga saat ini Uni Eropa (UE) selalu menjadi contoh sukses bagi negara-negara di kawasan. Hal ini dikarenakan negara anggota yang tergabung ke dalam Uni Eropa tetap bisa bersatu demi meraih kepentingan bersama, meskipun negara-negara anggota tersebut memiliki perbedaan kepentingan nasionalnya masing-masing. Tidak hanya itu saja, organisasi regional ini juga memiliki institusi-institusi yang berperan di bidang keamanan, politik, sosial dan budaya.

Dengan adanya kelengkapan lembaga-lembaga instrument ekonomi politik yang dimilikinya itulah, membuat Uni Eropa menjadi organisasi yang disegani oleh negara-negara maupun organisasi regional lainnya di dunia, karena peranannya yang aktif dalam pengawasan serta penjagaan terhadap perbatasan-perbatasan negara anggota dengan negara-negara non Eropa. Integrasi ekonomi, politik, keamanan dan kebudayaan ini juga berperan aktif

5Koran Tempo Edisi, 16 December 2004, Mimpi Turki di Eropa.https://koran.tempo.co/read/internasional/29320/mimpi-turki-di-eropa diakses pada 5 September 2021 
dalam upaya menyejahterakan masyarakat Eropa dengan memperkuat ekonomi setiap negara anggotanya sesuai dengan prinsip "Peace, Prosperity, and Progress". Itulah sebabnya, banyak negara-negara yang berbatasan langsung dengan Eropa ingin bergabung ke dalam organisasi tersebut, salah satunya yaitu Turki.

Dengan adanya latar belakang tersebut membuat penulis tertarik untuk membahas serta menganalisa hal-hal yang melatarbelakangi terhambatnya proses aksesi keanggotaan Turki. Pokok permasalahan utama yang akan dianalisa yaitu mengapa Turki sulit untuk bergabung menjadi keanggotaan penuh Uni Eropa dan selalu dinilai gagal oleh negara anggota Uni Eropa dalam memenuhi kriteria Kopenhagen. Adapun tujuan dari penulisan artikel ini yaitu untuk dapat mengetahui alasan Uni Eropa menolak untuk meresmikan Turki menjadi anggota penuh serta faktor-faktor penghambat yang membuat Turki gagal menjadi anggota Uni Eropa hingga sampai saat ini. Dalam melakukan penulisan ini, penulis menggunakan landasan teori regionalism. Dengan menggunakan teori regionalisme yang dapat diartikan sebagai koordinasi atau kerja sama dalam bidang ekonomi dan politik oleh negara-negara yang berdekatan secara geografis dapat dipahami mengapa Turki begitu berambisi untuk menjadi anggota Uni Eropa karena sebagian wilayahnya berada Benua Eropa dan sebagian di Asia. Selain itu, metode atau pendekatan yang digunakan oleh penulis yaitu metode atau pendekatan kualitatif. Adapun alasan mengapa penulis menggunakan metode kualitatif karena secara umum metode ini digunakan untuk menganalisa tentang tingkah laku, tindakan individu atau kelompok yang tersembunyi di balik fenomena maupun masalah yang kadangkala sulit untuk dipahami. Untuk teknik pengumpulan data yang digunakan oleh penulis terhadap penulisan artikel ini yaitu melalui studi literature atau studi pustaka yang di mana studi literature ini merupakan metode pengumpulan data yang dilakukan dengan mengambil referensireferensi melalui buku, jurnal, artikel serta media berita online yang relevan dengan pembahasan penelitian.

Dalam melakukan penelitian mengenai rekam jejak kegagalan Turki menjadi anggota Uni Eropa, terdapat beberapa jurnal maupun artikel sebagai bahan rujukan data untuk dapat menganalisa permasalahan yang dikaji. Rujukan pertama adalah tulisan dari Muhammad Sya'roni Rofii yang berjudul "Potret Diplomasi Turki menuju Keanggotaan Tetap Uni Eropa". Di dalam tulisannya, ia berpendapat bahwa usaha Turki terkait pemenuhan Kriteria Kopenhagen untuk menjadi keanggotaan penuh Turki benar-benar dilaksanakan sejak tahun 2003 yaitu ditandai dengan upaya yang dilakukan 
pemerintah Turki melakukan reformasi kebijakan ekonomi maupun politik dalam negeri dengan menyamakan kebijakannya sesuai dengan ketetapan yang diberikan oleh Uni Eropa. ${ }^{6}$ Dengan kata lain, pemerintah Turki ingin agar dapat melakukan koordinasi serta kerja sama dalam bidang ekonomi dan politik dengan negara-negara Eropa. Akan tetapi, usaha-usaha diplomasi Turki sia-sia, karena proses aksesi Turki sempat ditunda oleh Uni Eropa akibat permasalahan HAM, dan perlindungan terhadap suku minoritas kurdi di Turki.

Rujukan literature yang kedua adalah tulisan dari Samuel P. Huntington dalam bukunya Benturan Peradaban dan Masa Depan Politik Dunia "Clash of Civilizations and The Marking of World Order" yang berkesimpulan bahwa terdapat dua penilaian antara Elit Politik Turki dengan Elit Politik Uni Eropa yang saling berlawanan. Elit politik Turki mendefinisikan Turki sebagai bagian dari masyarakat Barat, sebaliknya Elit Barat tidak mengakui bahkan menolak untuk menerima Turki sebagai bagian dari mereka. ${ }^{7}$ Hal ini tidak terlepas dari sejarah peradaban terdahulu, dimana negara-negara Eropa memiliki sejarah peradaban Barat yang sama sedangkan sejarah peradaban Turki lebih kepada peradaban Timur, sehingga negara-negara Eropa menganggap bahwa Turki merupakan negara Non Barat yang notabene berbeda dengan Eropa. Sedangkan Rujukan literature yang terakhir yaitu merupakan tulisan dari Christoph Marcinkowskiyang berjudul "European Union with Turkey: The Possible Impact of Turkey's Membership on the European Union". Di dalam tulisannya membahas berbagai macam kemungkinan apabila Uni Eropa menerima permintaan Turki menjadi anggotanya. Menurut Marcinkowski, dampak positif yang terjadi apabila Turki berhasil menjadi salah satu anggota Uni Eropa yaitu Turki dapat menjadi salah satu mediator penghubung antara Uni Eropa dengan negaranegara di Timur Tengah maupun Asia. ${ }^{8}$

Selain itu, di dalam tulisannya, Marcinkowski membahas alasan mengapa proses keanggotaan Turki terkesan lama bahkan seperti ditolak. Hal ini diperkirakan karena adanya Islamphobia. Meskipun pada kenyataannya belum ada pernyataan resmi dari pihak Uni Eropa terkait hal tersebut, akan

6 M. Sya'roni Rofii, "Potret Diplomasi Turki Menuju Keanggotaan Tetap Uni Eropa," Op, Cit., hlm 89.

${ }^{7}$ Huntington, Samuel P. 1996, The Clash of Civilization and Remarking of World Order, New York : SIMON \& Schuster

${ }^{8}$ Christoph Marcinkowski, "European Union with Turkey: The Possible Impact of Turkey's Membership on the European Union," ProQuest Journal, Vol. I, Jss. 3 April 2010, hlm537. 
tetapi beberapa faktor yang terlihat seperti menunjukkan persepsi akan hal tersebut.

\section{Hasil dan Pembahasan}

Sepeninggal Inggris yang memilih Brexit pada 1 Feburari 2020 lalu, saat ini Uni Eropa beranggotakan 27 negara. Dari jumlah tersebut, tiga diantaranya adalah Polandia, Rumania dan Syiprus yang sama-sama berjuang dengan Turki untuk menjadi anggota Uni Eropa. Namun, berbeda dengan ketiga negara yang lainnya, Turki hingga kini masih tertinggal untuk dapat diterima sebagai anggota penuh. Berbagai isu mengganjal rencana keanggotaan Turki menjadi anggota organisasi supranasional yang ada di benua Biru itu.

Dalam hal ini, Turki dinilai belum memenuhi secara lengkap Kriteria Kopenhagen 'Copenhagen Criteria' yang merupakan syarat utama keanggotaan yang ditetapkan oleh Uni Eropa bagi negara yang ingin bergabung menjadi anggota. Kriteria Kopenhagen menjunjung tiga pilar utama, yakni Politik, Ekonomi dan Hukum. Pada pilar pertama yaitu Kriteria politik didasarkan pada stabilitas lembaga yang menjamin demokrasi, supremasi hukum, hak asasi manusia serta penghormatan serta perlindungan minoritas. Pilar kedua, yaitu Kriteria Ekonomi didasarkan pada keberadaan ekonomi pasar yang berfungsi serta kapasitas untuk mengatasi tekanan kompetitif dan kekuatan pasar di dalam lingkungan perdatangan Uni Eropa. Sedangkan pilar ketiga adalah upaya penyelarasan legislatif, yaitu kemampuan untuk membawa hukum calon negara anggota agar sejalan dengan Badan Hukum Eropa yang dibangun di atas sejarah Uni Eropa yang dikenal sebagai Acquis Communautaire.

Berbagai permasalahan yang terjadi baik permasalahan dalam negeri maupun dampak kebijakan luar negeri yang diambil Pemerintah Turki membuatnya dinilai belum dapat memenuhi Kriteria Kopenhagen. Konflik horizontal Turki kontra suku Kurdi yang terus berlangsung sejak tahun 1984 dan telah menelan korban jiwa dari kedua belah pihak. Beberapa peristiwa berdarah dilakukan Turki terhadap suku Kurdi antara antara lain serangan udara dan operasi darat 1936-1939 di bawah kepemimpinan Presiden Mustafa Kemal Atatürk yang telah menewaskan 13.800 orang suku Kurdi. ${ }^{9}$ Demikian pula ketika pada era 1980-an, Pemerintah Junta Militer Turki membuat Undangundang Anti-Teror yang kemudian dipakai untuk memburu warga Kurdi.

${ }^{9}$ Eks Menteri Turki Dirikan Partai untuk Hadang Erdogan (artikel online) melalui link https://dunia.tempo.co/read/1028098/eks-menteri-turki-dirikan-partaiuntuk-hadang-erdogan dikases pada 1 September 2021 
Ribuan orang Kurdi dibunuh oleh tentara militer Turki karena dianggap sebagai teroris dan simpatisan separatisme suku Kurdi di bawah bendera Partiya Kankeran Kurdistan (PKK). 10

Meski sempat melakukan gencatan senjata pada tahun 2013 lalu, namun kontak senjata antara Turki tak bisa terhindarkan. Dengan tujuan menciptakan keamanan bagi para pengungsi Suriah, militer Turki kerap memburu suku Kurdi yang bergabung dalam Pasukan Demokrasi Suriah (SDF) yang menguasai wilayah perbatasan. Akibat kontak senjata tersebut, puluhan ribu warga sipil meninggalkan rumah dan menyerbu Eropa untuk mencari suaka perlindungan demi kehidupan yang lebih baik. Situasi ini merupakan situasi yang sangat tidak menguntungkan bagi Eropa, karena imigran yang terus membanjiri Eropa.

Konflik Turki dengan suku Kurdi berawal dari janji Mustafa Kemal Atatürk, Presiden pertama Republik Turki yang akan memberikan kemerdekaan kepada suku Kurdi jika bersedia membantu Turki dalam melawan imprealisme Barat. Namun di saat kemenangan tiba suku Kurdi justru tidak mendapatkan apa yang telah dijanjikan. Padahal dalam Perjanjian Sevres (Treaty of Sevres) tahun 1920 antara pihak Sekutu sebagai pemenang Perang Dunia I dengan Dinasti Ustmaniah, Turki diharuskan memberikan keuntungan bagi perjuangan suku Kurdi. Dalam perjanjian yang ditetapkan di Prancis tersebut telah disepakati pembentukan wilayah Kurdistan Merdeka yang sebelumnya berada di bawah kekuasaan Dinasti Ustmaniah Turki, tetapi kenyataannya keputusan tersebut tidak terealisasikan. Turki menolak menjalankan ketentuan mengenai suku Kurdi, bahkan Mustafa Kemal Atatürk yang saat itu menjadi Presiden Turki pertama memaksa sekutu untuk membatalkan Perjanjian Sevres yang merugikan dan melemahkan Turki karena perbatasan timur negara Turki memanjang hingga Sulaymaniah, Arbil, Kirkuk, dan Mosul berada di utara wilayah Irak sekarang. ${ }^{11}$

Serangan militer berkala terhadap separatis Kurdi telah menggusur sebagian penduduk di tenggara Turki dan memicu kecaman internasional. Turki menganggap suku Kurdi sebagai gerakan separatis yang ingin memisahkan diri dengan membentuk negara pemerintahan sendiri. Hal ini tentu saja ditolak oleh

10 Diperangi Erdogan, tak diakui di Suriah, siapa sesungguhnya bangsa Kurdi? (artikel online) melalui https://www.bbc.com/indonesia/dunia-50068256 diakses pada 4 September 2021

11 Johanna Können, Cultural Diplomacy and the Debate on Turkey's Accession to the EU (paper online) melalui link http://www.culturaldiplomacy.org/pdf/casestudies/cd-debate.pdf diakses pada 4 September 2021 
Pemerintah Turki karena dapat menjadi ancaman desintegrasi bangsa. Sebenarnya, Turki bukan satu-satunya negara yang berkonflik dengan etnis Kurdi, beberapa negara lainnya yang juga berkonflik dengan etnis ini antara lain Suriah, Irak, dan Iran.

Sebagai salah satu penduduk asli daratan Mesopotamia, suku kurdi menempati dataran tinggi di Turki bagian tenggara, Suriah di bagian barat laut, Irak di bagian utara, sedangkan Iran di bagian barat laut dan barat daya dengan Armenia. Etnis Muslim Sunni yang tersebar di berbagai negara ini kemudian bersatu melalui persamaan ras, budaya, bahasa untuk membentuk negara berdaulat sehingga suku Kurdi dapat mengatur diri dan mempertahankan identitas serta sistem budaya mereka. Karena keinginan untuk menjadi bangsa merdeka dan memiliki negara otonom yang berdaulat itulah menyebabkan etnis Kurdi harus berhadapan dengan 4 negara salah satunya adalah Turki. ${ }^{12}$

Perlakuan atas suku minoritas di Irak, Iran, Suriah dan Turki menjadikan Etnis Kurdi memisahkan diri dari negara induk masing-masing dan mewujudkan cita-cita menjadi negara Kurdistan yang merdeka dan demokratis ${ }^{13}$. Konflik-konflik tersebut menjadi pemicu lahirnya para imigran yang membanjiri negara-negara Eropa melalui Turki sebagai pintu gerbang menuju Eropa. Padahal, seperti diketahui, masalah pengungsi menjadi salah satu hal yang sangat dihindari oleh negara-negara anggota Uni Eropa. Selama proses pengajuan untuk menjadi anggota tetap, Turki juga kerap bersitegang dengan negara-negara superior anggota Uni Eropa diantaranya Jerman dan Prancis. Jika dilihat kembali ke masa lalu Perancis, Jerman bersama Inggris merupakan tiga negara besar yang mempelopori berdirinya Uni Eropa. Ketiganya merupakan negara besar baik itu di dalam regional eropa maupun di dalam organisasi Uni Eropa itu sendiri, meskipun dalam perjalanannya Inggris memilih untuk hengkang pada 1 Februari 2020 lalu.

Sejak dulu Jerman dikenal sebagai negara industri paling maju di Eropa, bahkan dunia hingga saat ini. Jerman menjadi negara pertama di Eropa yang mendirikan kementerian pembangunan, pada tahun 1961. Saat ini, Jerman

12 M.Riza Sihbudi, M., Islam, Dunia Arab, Iran: Barat Timur Tengah. Bandung: Mizan 1991

13 Andina Sari, Saiful Bachri, Jurnal Upaya Pemerintah Turki Dalam Mengatasi Gerakan Separatisme Suku Kurdi Tahun 1984-2007 (e-book) melalui link http://download.garuda.ristekdikti.go.id/article.php?article=1413075\&val=4059 diakses pada 1 September 2021 
adalah pemegang saham terbesar keempat Bank Dunia14. Dengan kekuatan ekonomi dan teknologi yang dimilikinya menjadikan Jerman sebagai negara yang disegani dan dianggap sebagai pemimpin ketika ide penyatuan eropa terbentuk. Jerman merupakan penyumbang anggaran terbesar Uni Eropa, juga dikenal sebagai negara yang sangat ketat mengawal terpenuhinya Kriteria Kopenhagen bagi setiap negara yang akan masuk menjadi anggota baru, termasuk Turki.

Sebenarnya Turki dan Jerman merupakan negara yang saling ketergantungan, Jerman banyak bergantung kepada Turki dalam membendung arus pengungsi dari Timur Tengah, Turki juga merupakan mitra bisnis penting bagi Jerman. Namun, kedua negara kerap terperangkap dalam konflik seperti Presiden Recep Tayyip Erdoğan yang melancarkan tuduhan bahwa Jerman menerapkan cara Nazi ketika melarang pejabatnya bertemu dengan warga Turki di Jerman. Penangkapan warga negara Jerman oleh pemerintah Turki atas tudingan keterlibatan dugaan afiliasi dengan gerakan oposisi yang mengkudeta Erdogan pada 15 Juli 2016. Akibatnya, Pemerintah Jerman memberlakukan travel warning kepada warganya yang akan masuk wilayah Turki. Bahkan buntut dari ketegangan itu, sebagian warga Turki mendesak agar Turki keluar dari NATO. Baru-baru ini sebuah insiden juga membuat Jerman geram.

Belum lama ini sebuah insiden kembali menyulut kemarahan Jerman dan anggota Uni Eropa. Presiden Komisi Eropa, Ursula von der Leyen yang merupakan kebangsaan Jerman, secara terbuka menceritakan pengalamannya yang kurang menyenangkan saat bertemu dengan Presiden Erdogan di Ankara pada awal April 2020. Tokoh penting Jerman dan Uni Eropa tersebut tidak diberikan kursi oleh Tim Protokol Turki saat Presiden Dewan Eropa Charles Michel bertemu dengan Erdogan untuk membicarakan ketegangan hubungan antara Uni Eropa dan Turki. Ia pun mengaku sakit hati dan merasa terpinggirkan. ${ }^{15}$

Selain Jerman, Turki juga kerap terlibat ketegangan dengan Prancis, padahal seperti halnya Jerman, dengan kekuatan yang dimilikinya

\footnotetext{
14 The World Bank In Germany Overview melalui link (situs resmi)

https://www.worldbank.org/en/country/germany/overview diakses pada 6 September 2021

15 Presiden UE sakit hati soal tempat duduk saat jumpa Erdogan melalui link https://www.cnnindonesia.com/internasional/20210427094337-134635203/presiden-ue-sakit-hati-soal-tempat-duduk-saat-jumpa-erdogan diakses pada 2 Agustus 2021
} 
menyebabkan Prancis paling didengar dalam setiap forum Uni Eropa khususnya dan antar negara-negara Eropa lainnya. ${ }^{16}$ Hal ini tidak lepas dari sejarah berdirinya Uni Eropa, bersama-sama Jerman dan Inggris, Prancis adalah salah satu negara pendiri Uni Eropa dan merupakan salah satu negara penting di dunia internasional.

Ada beberapa realitas terkait konflik internasional antara Turki dan Prancis, antara lain dalam keterlibatan kedua negara terhadap perang di Suriah, Nagorno-Karabakh dan Libya. Turki dan Perancis memberikan dukungan pada pihak yang berbeda sesuai dengan kepentingan nasionalnya masing-masing. Di Libya misalnya Prancis memberikan dukungan kepada Libyan National Army (LNA) di sisi yang berlawanan Turki justru memberikan dukungan berupa tentara bayaran terhadap Government of National Accord (GNA). Prancis juga kerap dibuat berang dengan kebijakan Turki yang memberikan dukungan kepada negara-negara Afrika yang berada dalam penguasaan Prancis. Yang terbaru dan tengah memanas adalah klaim Prancis bahwa angkatan laut Turki telah mengganggu salah satu kapal perang Prancis yang sedang menjalankan misi NATO di wilayah perairan Mediterania. ${ }^{17}$ Di saat bersamaan Turki memang sedang meningkatkan agrevitasnya di perairan Mediterania yang berbatasan langsung dengan Siprus Utara sebagai upaya mempertahankan wilayah teritorialnya.

Presiden kedua negara juga kerap saling serang pernyataan seperti ketika Erdogan menyatakan kemarahannya terhadap Emmanuel Macron terkait isu penghinaan terhadap Nabi Muhammad SAW yang diwarnai dengan ajakan Erdogan terhadap umat Islam dunia untuk memboikot produk Prancis. Dia juga menuduh Macron Islamophobia dan mendesak para pemilih Prancis untuk menyingkirkan Macron dari kursi kepresidenan sesegera mungkin. Konflik kedua negara bahkan merambah ke konflik personal. Sebagai kepala negara, Presiden Erdogan memang dikenal sebagai sosok yang memiliki sikap keras dan tegas bahkan tidak jarang sikapnya itu kerap membuat berang pihak-pihak yang bersebrangan dengan kepentingan nasional Turki. Hal itu tercermin dalam

16 Triesanto Romulo Simanjuntak Dan Drs Dafri Agussalim, Sikap NegaraNegara Anggota Uni Eropa Dalam Menangani Krisis Yunani (Studi Kasus: Sikap Jerman, Perancis dan Inggris) melalui link Menapak Tonggak Sejarah Pembentukan Uni Eropa" dalam http://www.antaranews.com diakses pada 06 September 2021.

17 Turki Buka-bukaan Soal Konflik Yunani, Libya, dan Prancis melalui link https://republika.co.id/berita/qck668440/turki-bukabukaan-soal-konflik-yunanilibya-dan-prancis diakses pada 06 September 2021 
berbagai kebijakan luar negeri yang diambilnya dalam menghadapi negaranegara maju seperti Prancis, Jerman bahkan AS sekalipun.

Dengan area seluas $783.562 \mathrm{~km}^{2}$; negara ini lebih dari dua kali ukuran Jerman dengan jumlah penduduknya 83,6 juta pada tahun 2020. ${ }^{18}$ Menurut data World Bank, jumlah penduduk Jerman tercatat 83 juta sedangkan Prancis, 64 juta pada tahun 2021. Keberadaan Turki tentu bisa menjadi ancaman tersendiri bagi negara-negara besar anggota Uni Eropa, khususnya Jerman dan Prancis yang selama ini dikenal sangat dominan di Uni Eropa. Hal ini didasarkan pada sistem poling di Uni Eropa yang menguntungkan negara berpopulasi besar seperti yang selama ini diberikan kepada Jerman dan Prancis. Uni Eropa menganut sistem poling atau aklamasi dalam mengambil keputusan. Tidak hanya itu, jatah kursi di Dewan Eropa juga berdasarkan jumlah penduduk suatu negara selama ini. Oleh sebab itu, dengan jumlah penduduk yang lebih besar dari negara lain, Turki akan memiliki posisi yang sangat strategis dalam setiap pembuatan keputusan yang dilakukan oleh Uni Eropa.

Selain kerap perselisihan dengan Prancis dan Jerman sebagai negara dominan di tubuh Uni Eropa, Turki juga terlibat ketegangan dengan anggota Uni Eropa lainnya yaitu Yunani. Pertama, konflik terkait Siprus, meski pulau Siprus telah dibagi menjadi pemerintah Siprus Turki di utara dan administrasi Siprus Yunani di selatan sejak kudeta militer 1974 yang ditujukan pada aneksasi Siprus oleh Yunani namun hingga kini belum terpecahkan Siprus tetap belum terpecahkan. Berbagai upaya perdamaian bahkan dilakukan oleh PBB. Suhu ketegangan yang meningkat baru-baru ini di Mediterania Timur bahkan semakin memperumit masalah. Dalam sebuah kesempatan Pemerintah Turki melalui Presiden Erdogan menyatakan siap perang melawan Yunani dalam kasus rebutan sumber daya migas di laut Mediternia Timur. ${ }^{19}$ Turki dan Yunani sama-sama mengklaim sebagai pemilik kawasan kaya minyak dan gas bumi tersebut. Dalam laporan US Geological Survey, Laut Mediterania Timur memiliki cadangan minyak 1,7 miliar barel dan cadangan gas 3,5 triliun meter kubik ${ }^{20}$. Keberatan Yunani atas agresivitas Turki tersebut telah dilaporkan kepada Uni Eropa. Para pemimpin Uni Eropa terus memperingatkan sanksi terhadap Turki

\footnotetext{
18Populasi Turki tembus 83,6 juta pada 2020 melalui link https://www.aa.com.tr/id/dunia/populasi-turki-tembus-83-6-juta-pada2020/2133424 diakses pada Sabtu, 11 September 2021

${ }^{19}$ Erdogan Siap Perang Lawan Yunani, Ini Penyebabnya!, melalui link https://www.cnbcindonesia.com/news/20200831091027-4-183166/erdogan-siapperang-lawan-yunani-ini-penyebabnya diakses pada 5 September 2021

20 ibid
} 
jika negara itu terus mengeksplorasi gas dan minyak di perairan yang diperebutkan. Ketegangan ini tentunya suka tidak suka menjadi penghalang kemajuan negosiasi Turki untuk bergabung dengan Uni Eropa.

Faktor penyebab lain yang menjadikan Turki belum meraih cita-cita untuk menjadi anggota penuh Uni Eropa adalah persoalan ekonomi yang dinilai tidak stabil. Stabilitas ekonomi berdampingan dengan syarat lainnya yaitu demokrasi, supremasi hukum, penghargaan terhadap HAM dan kaum minioritas sebagaimana diatur dalam Treaty on the European Union. Permasalahannya selama ini Turki memiliki kendala dalam menjaga stabilitias dan ketahanan ekonomi dalam negeri. Meskipun telah melakukan sistem ekonomi pasar bebas sebagaimana yang berlaku di Uni Eropa, pertumbuhan ekonomi Turki memang masih belum cukup menggembirakan akibat kondisi politik dan keamanan yang kerap diwarnai pergolakan seperti peristiwa kudeta oleh faksi militer terhadap Presiden Erdogan pada 15 Juli 2016 lalu yang menewaskan ratusan orang dan berbuntut penangkapan ribuan orang, situasi ini tentunya secara tidak langsung berdampak pada pertumbuhan sektor ekonomi.

Sebenarnya, sebelum masa pandemi yang menghantam dunia, ekonomi Turki meningkat cukup drastis. Pemerintah Turki telah mengalami kemajuan dalam memenuhi kriteria-kriteria calon anggota yang diberikan oleh Uni Eropa, Turki menunjukkan pertumbuhan ekonomi yang menjanjikan. Turki bahkan dijuluki sebagai sebagai ekonomi negara menuju maju (emerging market) oleh IMF. Menurut CIA World Fatchbook, Turki disebutkan sebagai negara dengan PDB nominal terbesar ke-dan PDB menurut PPP terbesar ke-17 di dunia21. Selain itu, Turki juga masuk dalam jajaran produsen terkemuka di dunia dalam produk pertanian, tekstil, kendaraan bermotor, kapal, sarana transportasi, bahan bangunan, elektronik konsumen hingga peralatan rumah tangga. ${ }^{22}$

Bahkan World Bank mengakui Kinerja pembangunan ekonomi dan sosial Turki sejak awal 2000-an sangat mengesankan, yang ditandai dengan peningkatan lapangan kerja dan pendapatan dan menjadikan Turki sebagai negara berpenghasilan menengah ke atas. Demikian pula sepanjang tahun 20042008 pertumbuhan ekonomi Turki tercatatat mencapai rata-rata $7 \%{ }^{23}$. Selama waktu ini, Turki dengan cepat melakukan urbanisasi, mempertahankan

${ }^{21}$ Turkey in brief (situs resmi Turkey yang dikutip oleh Deplu RI) melalui link https://www.nationsonline.org/oneworld/turkey.htm diakses pada 9 September 2021 22 Ibid,

23 The Worl Bank in Tureky Overview (release resmi) melalui https://www.worldbank.org/en/country/turkey/overview diakses pada Sabtu, 11 September 2021 
kerangka kebijakan makro ekonomi dan fiskal yang kuat, membuka perdagangan dan keuangan luar negeri, menyelaraskan banyak undang-undang dan peraturan dengan standar Uni Eropa (UE), dan sangat memperluas akses ke layanan publik. Ini juga pulih dengan baik dari krisis keuangan global pada tahun 2008-2009.24

Demikian pula pada 2012, melalui data World Bank tercatat pada tahun 2012 GDP turki menunjukkan pertumbuhan positif sebesar 4.79\%, lalu naik tajam di tahun 2013 sebesar 8.491\%. Ini membuat Turki masuk kedalam 20 negara besar terkuat (G20) pada tahun 2015. Meskipun laju pertumbuhan ekonomi Turki berkembang dengan pesat, akan tetapi tidak serta merta mencerminkan kondisi ekonomi negaranya yang tangguh jika dihantam badai. Terbukti pada tahun 2018, Turki mengalami resesi yang digambarkan dengan menurunnya nilai tukar mata uang lira terhadap dolar Amerika Serikat. Hal ini dikarenakan oleh beberapa faktor, salah satunya yaitu sikap teguh presiden Erdogan yang menolak meningkatkan suku bunga bank sentral menjadikan inflasi dan devaluasi semakin dalam karena karena cadangan devisa terus menyusut dengan cepat. Selain itu, Hubungan Turki dengan Amerika Serikat yang tidak harmonis juga ikut menyebabkan krisis ekonomi di Turki.

Melihat hal tersebut, pemerintah Turki di bawah kepemimpinan Erdogan menerapkan status State of Emergency dan melakukan berbagai macam strategi dalam mengatasi krisis ekonomi di negaranya yang diantaranya, yaitu menaikkan tarif impor komoditas dari Amerika Serikat, meminta seluruh warganya agar menjual Dollar dan Euro untuk membantu pemulihan mata uang lira serta memanfaatkan dukungan dari negara-negara sekutu. Tidak hanya itu, Erdogan pun juga menekankan kegiatan ekspor dan pariwisata sebagai usaha memperbaiki ekonominya. Perlahan tapi pasti, perekonomian Turki mulai menunjukkan peningkatan. Meskipun dilanda pandemi Covid-19 ditambah dengan situasi politik yang terus bergejolak akibat aksi para oposisi Presiden Erdogan, Turki mampu mempertahankan posisinya sebagai salah satu ekonomi dengan pertumbuhan tercepat di dunia selama dua tahun ini. Meskipun demikian, Uni Eropa tetap tidak menjadikan Turki sebagai anggota tetapnya. Hal ini berbanding terbalik dengan negara Kroasia yang permintaannya untuk menjadi anggota diterima oleh Uni Eropa meskipun GDPnya tercatat hanya di angka $0.549 \%$ dan jauh dibawah Turki. ${ }^{25}$

\footnotetext{
${ }^{24}$ Ibid,

25 World Bank Turkey"s GDP 2012- MKTP.KD.ZG?end=2013\&locations=TR\&sta $\mathrm{rt}=2012$
} 
Penolakan demi penolakan yang terus dilancarkan Uni Eropa, tidak membuat Turki berhenti dalam mencapai cita-citanya masuk dalam keanggotan penuh. Sejak pencalonan sebagai anggota baru disetujui Uni Eropa dalam KTT Uni Eropa yang digelar di Helsinki, Finlandia pada 10 Desember 1999, berbagai strategi dilakukan Turki baik pendekatan jalur diplomasi maupun dengan menerapkan berbagai kebijakan sebagaimana disyaratkan Uni Eropa. Adapun alasan Turki ingin bergabung menjadi keanggotaan Uni Eropa dilatarbelakangi oleh dua faktor, yaitu faktor ekonomi dan politik. Dari segi ekonomi, keikutsertaan Turki menjadi anggota tetap Uni Eropa akan berdampak positif bagi kestabilan dan kekuatan ekonomi Turki. Hal ini dikarenakan Turki dapat memperluas pasar bebas hingga ke negara-negara di Eropa karena tidak adanya hambatan akan tarif distribusi. ${ }^{26}$

Sedangkan dari segi politik, keikutsertaan Turki menjadi bagian dari keanggotaan Uni Eropa dapat memperluas pengaruhnya ke negara-negara Eropa serta memperkuat kekuatan militernya. Apabila Turki berhasil bergabung kedalam Uni Eropa, maka kekuatannya di tingkat regional maupun internasional akan menjadi semakin kuat karena. Dengan kata lain, jika Turki berhasil mendapatkan keanggotaannya di Uni Eropa akan memiliki kekuatan yang besar di dua sisi yaitu politik dan ekonomi. Turki menggunakan berbagai instrumen untuk mampu meyakinkan pihak Uni Eropa terkait komitmen mereka untuk memenuhi semua standar yang telah ditetapkan oleh Uni Eropa. Sejauh ini Turki memaksimalkan langkah-langkah diplomasi untuk memastikan citra Turki jauh lebih baik dibandingkan sepuluh tahun silam. Kini, dengan pendekatan diplomasi pula Turki ingin membangun citra internasional sebagai salah satu negara kunci di kawasan Timur Tengah dan terlibat aktif menjalin hubungan baik dan mengawal isu-isu strategis di kawasan. ${ }^{27}$

Berbagai strategi dilakukan Turki antara lain: dalam penegakan HAM, pemerintah Turki mengeluarkan berbagai kebijaka seperti penghapusan hukuman mati. Reformasi hukum pidana dan pemberantasan korupsi. Menjamin hak-hak penyandang cacat dalam bekerja dan mendapatkan

26 Ilham Ozturk dan Kamil Sertoglu, "Turkey and European Union Relations : Concept of the Custom Union," Pakistan Horizon, Vol.56, No.3, 2003, melalui link https://mpra.ub.uni-muenchen.de/333/1/MPRA_paper_333.pdf; dan diakses pada 25 Agustus 2021

${ }^{27}$ Potret Diplomasi Turki Menuju Keanggotaan Tetap Uni Eropa M. Sya'roni Rofii Mahasiswa Doktoral pada Marmara University Turkey 
pekerjaan yang layak. Melakukan pelatihan tentang Hak Asasi Manusia terhadap para sipir di rumah tahanan/penjara yang diharapkan mampu mengendalikan situasi jika setiap saat terjadi kekacauan agar tidak terjadi pelanggaran HAM. Mengeluarkan sejumlah peraturan yang melindungi hak warga negara, termasuk penggunaan hijab yang menjadi sorotan Uni Eopa. Seperti diektahui, bagi Uni Eropa hijab merupakan bagian dari hak berkeyakinan yang harus dilindungi.

Dalam hal penegakan demokrasi, sebagaimana laporan dari publikasi Turkey Progress pada tahun 2010 sampai tahun 2016, pemerintah Turki melakukan program demokratisasi seperti upaya yang meliputi adanya akses peradilan kepada publik secara oline. Mengurangi kewenangan dan pengaruh Menteri Kehakiman sehingga diharapkan mampu menjamin peradilan yang independen tanpa banyak intervensi dari otoritas Turki. Memberikan hak bagi individu untuk mengajukan petisi ke Mahkamah Konstitusi. Melakukan Strategi Anti Korupsi dengan mengawasi pembiayaan partai politik termasuk sumber pendanaan kampanye dan membentuk ombudsman yang bertugas menerima aduan tentang tindakan korupsi. ${ }^{28}$

Sedangkan dalam pemberantasan terorisme, usaha yang dilakukan oleh pemerintah Turki yaitu menggelar dua operasi militer Angkatan Bersenjata Turki (TSK) untuk melawan organisasi dan kelompok-kelompok terror di utara Suriah. Dengan adanya operasi yang dilakukan oleh Turki di wilayah utara Irak dapat menghadang aktivitas penyeberangan perbatasan ilegal serta melumpuhkan para petinggi organisasi teroris pemberi keputusan semua kegiatan teror.

Demikian pula dalam perbaikan politik, Pemerintah Turki juga terus berjuang keras untuk menyelesaikan berbagai masalah yang dipersoalkan Uni Eropa seperti upaya keras untuk menyelesaikan masalah dengan suku Kurdi, Armenia, dan Siprus serta meminimalisir Peran Militer dalam dunia perpolitikan. Menghargai hak-hak minoritas seperti suku Kurdi, ditandai dengan diperbolehkannya menggunakan bahasa Kurdi dan perayaan tradisi Kurdi. Melakukan liberalisasi ekonomi sesuai standar UE. ${ }^{29}$ Semua itu dilakukan Turki demi memenuhi persyaratan yang diajukan oleh Uni Eropa sebagaimana

\footnotetext{
28 Turkey in preparing for EU membership melalui link https://ec.europa.eu/neighbourhoodenlargement/sites/near/files/pdf/key_documents/2010/package/tr_rapport_2010_en .pdf diakses pada Sabtu 4 September 2021

${ }^{29}$ M. Sya'roni Rofii, Potret Diplomasi Turki Menuju Keanggotaan Tetap Uni Eropa, Marmara University Turkey, 2017
} 
tertuang dalam Kriteria Kopenhagen. Namun seiring dengan usaha-usaha yang telah dilakukan tersebut pada kenyataannya Turki masih mengalami kendala untuk bisa menjadi anggota Uni Eropa yang sudah lama dicita-citakan sejak beberapa dekade karena hingga kini Turki masih belum berhasil menjadi anggota penuh Uni Eropa. 30

Gagalnya strategi yang telah dilakukan Turki seiring kuatnya perlawanan sejumlah anggota Uni Eropa memunculkan analisa bahwa hal itu disebabkan oleh faktor lain, yaitu lantaran tidak sesuai dengan semangat Uni Eropa karena Turki adalah negara dengan mayoritas penduduk Muslim. Meskipun Turki telah membangun struktur secular di era kepemimpinan Presiden pertama Turki, Mustafa Kemal Atatürk, karena memiliki populasi dominan Muslim, pada kenyataannya Turki tidak dianggap sebagai negara yang benar-benar sekular oleh beberapa orang di Eropa. Apalagi di bawaha kepempinan Presiden Erdogan dengan latar belakang sebagai Ikhwannul Muslimin, Sunni memperkokoh kembali Turki sebagai negara Islam. Sebagai negara dengan populasi masyarakat dominan Muslim dan memiliki akar sejarah Islam, Turki dianggap tidak memiliki kecocokan dengan budaya Eropa yang lebih didominasi oleh Kristen. Islam tidak dipahami sebagai agama yang hanya memuat doktrin ritual, tetapi ditafsirkan sebagai ideologi yang bisa dihadapkan dengan ideologi modern seperti kapitalisme, liberalisme atau sosialisme. ${ }^{31}$

Sebagai negara yang mayoritas penduduknya muslim, kehadiran Turki dngan jumlah penduduknya 83,6 juta jiwa dan 75 persennya pemeluk Islam jika disetujui sebagai anggota baru Uni Eropa tentu akan mendongkrak jumlah penduduk Muslim di eropa jumlah muslim warga Uni Eropa bisa melonjak dari 5 persen menjadi 20 persen. Penolakan mengenai perbedaan kultur dan agama memang tidak pernah disampaikan Uni Eropa seacara resmi tetapi dapat dipahami secara rasional melalui berbagai analisis dan thesis para ahli. Dalam bukunya yang berjudul Benturan Peradaban dan Masa Depan Politik Dunia "Clash of Civilizations and The Marking of World Order", Samuel Huntington menguraikan bahwa persoalan kultural akan menjadi sumber konflik yang dominan di dalam politik global. Perbedaan peradaban akan sangat rentan

${ }^{30}$ Adhi Wardana, dalam jurnal Global Political Studies Jurnal berjudul Upaya Pemerintah Turki Untuk Bergabung Dengan Uni Eropa, Bandung 2017 melalui link https://ojs.unikom.ac.id/index.php/gps/article/download/2015/1356/ diakses pada 29 Agustus 2021

${ }^{31}$ Roy Oliver, The Failure of Political Islam. Terjemahan Carol Volk. Cambridge, MA: Harvard University Press. 1994 
memicu terjadinya konflik. Bila hal tersebut terjadi, maka akan muncul suatu kondisi yang disebut Huntington sebagai clash of civilisations. Indikasi terjadinya clash of civilisations tersebut dapat dilihat dalam hubungan Turki dan Uni Eropa. ${ }^{32}$ Populasi Muslim dan sejarah Islam Turki tetap dianggap sebagai suatu hal yang tidak cocok dengan kultur Eropa. ${ }^{33}$

Representasi lain yang muncul menunjukkan adanya hubungan Barat dan Islam yang banyak diwarnai oleh berbagai konflik yang dianalogikan sebagai benturan. ${ }^{34}$ Huntington menjelaskan tentang faktor-faktor yang telah dan akan berpotensi dapat meningkatkan panasnya konflik antara Islam dan Barat, dengan dukungan dan realitas pertumbuhan penduduk Muslim yang cepat di negara-negara Muslim. Cara pandang Hutington membuat dunia Barat sensitif melihat perkembangan dunia Islam dalam berbagai bidang. Sikap Barat lebih mencurigai program nuklir dan senjata-senjata berat di dunia Islam, dibandingkan dengan isu nuklir di negara Yahudi atau komunis memberikan pandangan bahwa Islam merupakan alternatif musuh utama Barat, setelah komunis. ${ }^{35}$ Sebuah situasi yang harus diwaspadai oleh Eropa sebagai representasi Non Muslim. Menurut Huntington, konflik besar yang terjadi pada abad 20 adalah konflik antara Muslim dengan non-Muslim. Oleh sebab itu, menurut Huntington, Eropa dan AS perlu menerapkan strategi bersama untuk menghadapi ancaman-ancaman yang dapat mengganggu keamanan dan masyarakat mereka dari para teroris yang merupakan militan Islam. ${ }^{36}$

Anggota Komisi Eropa dari Belanda Fritz Bokestein bahkan sudah memberi peringatan bernada ancaman "Islamisasi" Eropa, dengan mengingatkan peristiwa sejarah ketika Turki mengepung Wina pada 1683. Sekitar 200 ribu Ottoman bersenjata telah menembus sejauh dan mengepung Wina. Pemerintah Belanda beranggapan bahwa multikulturalisme tidak dapat

${ }^{32}$ Faidah Rahim, Clash of Civilisations: Hambatan Aksesi Turki ke Uni Eropa, Mahasiswi Program Studi Hubungan Internasional FISIP UPN "Veteran" Jawa Timur, 2013 melalui link https://core.ac.uk/download/pdf/19892242.pdf diakses pada 1 September 2021

33 Oner, Selcen. 2009. "Turkey's Membership to the EU in Terms of 'Clash of Civilization'” [online]. dalam libris.bahcesehir.edu.tr/dosyalar/A.../AE0096.pdf diakses 8 September 2021.

34 Bassam Tibb, Islam between Culture and Politics. New York: Palgrave Publishers Ltd., 1997

35 Ibid hal 25

${ }^{36} \mathrm{Dr}$. Agnes Setyowati H., M. Hum, IDEOLOGI ISLAM,BARAT, DAN AMERIKA Potret Sejarah Global Kepentingan dalam Pertarungan Diskursif, Suluh Media, Yogyakarta, 2017. 
dijadikan sebuah identitas nasional di Belanda dan tidak efisien untuk membentuk sebuah integrasi antar masyarakat di Belanda. Untuk itu pemerintah Belanda menuntut adanya penyesuaian bagi penduduk yang dianggap memiliki budaya minoritas untuk mengikuti budaya penduduk mayoritas. ${ }^{37}$ Belanda sebagai salah satu anggota Uni Eropa tidak menyukai multikultirisme dan masukanya Turki yang penduduknya mayoritas Muslim semakin memperkuat ketakutan itu.

Sikap Islamofobia merebak dengan mudah di kalangan masyarakat Barat sebagaimana telah disimpulkan Samuel Huntington dan para ilmuwan lainnnya. Barat menilai Islam bukan sekedara agama melainkan telah menjadi ancaman tersendiri bagi Barat, sehingga gejala paranoid terhadap Islam tampak dalam berbagai kebijakan negara-negara Barat. ${ }^{38}$ Hal ini sebenarnya, tentu menjadi kontra produktif mengingat pemenuhan kriteria politik yang dirumuskan oleh Uni Eropa adalah konsekuensi hukum dan politik dari prinsipprinsip dasar Uni Eropa sebagaimana tercantum dalam Pasal 6 dalam Perjanjian Amsterdam dan Nice. Pasal 6 (1) Treaty on European Union (TEU) menyatakan: "Uni Eropa didirikan berdasarkan prinsip-prinsip kebebasan, demokrasi, penghormatan terhadap hak asasi manusia, perlindungan minoritas dan supremasi hukum", nilai-nilai ini umum bagi negara-negara calon anggota Uni Eropa. Mengenai nilai-nilai perhimpunan, Pasal 2 dari Konstitusi Eropa menyatakan bahwa: Serikat ini didirikan atas dasar penghormatan terhadap hak asasi manusia, kebebasan berpendapat, demokrasi, kesetaraan gender, aturan hukum, dan penghormatan terhadap minoritas. Nilai-nilai ini umum bagi negara-negara yang sudah menjadi anggota Uni Eropa dalam masyarakat pluralisme, toleransi, keadilan, solidaritas, dan non diskrimanasi. ${ }^{39}$

Terlepas dari upaya yang dilakukan Turki untuk menjadi anggota Uni Eropa, Penduduk muslim Eropa juga terus mengalami peningkatan dari waktu ke waktu seiring tingginya migrasi penduduk dari negara-negara Timur Tengah yang negaranya dilanda konflik seperti Suriah, Irak, Afghanistan, dan Eritrea sejak 2017. Sementara itu, penduduk Muslim Eropa saat ini berjumlah atau 5

37 Sara De Luca, Albrecht Glitz, dan Francesc Ortega. 2013. Immigration in Europe: Trends, Policies, and Empirical Evidence. IZA

38 ibid

${ }^{39}$ Dr. Erich Hochleitner, The Political Criteria of Copenhagen and their application to Turkey, Working Paper, Austrian Institute for European Security Policy August 2005, Hal.2 
persen dari keseluruhan penduduknya. Muslim adalah minoritas yang relatif kecil di eropa, membentuk sekitar 5\% dari populasi. Namun, di beberapa negara, seperti Prancis dan Swedia, jumlah penduduk Muslim lebih tinggi. Dan, dalam beberapa dekade mendatang, bagian Muslim dari populasi benua itu diperkirakan akan tumbuh dan bisa lebih dari dua kali lipat. ${ }^{40}$

Dari pertengahan 2010 hingga pertengahan 2016 saja, persentase Muslim meningkat satu persen. Dari 19,5 juta menjadi 25,8 juta jiwa. Pew research menganalisis, pada 2050 bisa meningkat dua kali lipat. Faktor utama peningkatan Muslim di Eropa adalah banyaknya migran yang datang. Meski nantinya izin masuk migran ke Eropa dibatasi, populasi Muslim tetap akan meningkat sekitar 7,4 persen. Ini karena Muslim di Eropa masih berusia muda dan memiliki tingkat kesuburan yang tinggi. Wanita Muslim di Eropa pada umumnya memiliki satu anak lebih banyak dibandingkan wanita non Muslim liannya. Skema ini seperti hasil penelitian yang dilakukan Pew Research Center pada 2017 disebutkan terus berulang setiap tahun sehingga menjadi faktor penyumbang bertambahnya penduduk Muslim di Eropa. Para migran ini yang hijrah ke Eropa pada umumnya memiliki dua tujuan utama, yakni mencari suaka dan memperbaiki keadaan ekonomi atau mencari pekerjaan yang layak. Gelombang migran ini masuk memadati Eropa melalui Turki sebagai negara yang menjadi penghubung antara kawasan Timur Tengah dan Eropa. ${ }^{41}$

Berdasarkan data dari Konsulat Jendral Republik Indonesia Instanbul Turki menyebutkan bahwa 98 persen dari 83,6 juta pada tahun 2020 beragama Islam. ${ }^{42}$ Dengan bergabungnya Turki yang memiliki jumlah populasi lebih besar dibanding dengan negara-negara Eropa lainnya, maka penduduk Muslim Eropa tentunya akan semakin bertambah. Situasi yang tentunya bertolak belakang

${ }^{40}$ Conrad Hackett dalam 5 facts about the Muslim population in Europe, 2016 melalui link https://www.pewresearch.org/fact-tank/2017/11/29/5-facts-about-themuslim-population-in-europe/ diakses pada 2 September 2021

41 Ratna Ajeng Tejomukti/ Red: Nashih Nashrullah, 13 Negara Eropa yang Muslimnya Diprediksi Jadi Mayoritas diposting pada Rabu 17 Feb 2021 05:59 WIB melalui link https://www.republika.co.id/berita/qon91c320/13-negara-eropa-yangmuslimnya-diprediksi-jadi-mayoritas diakses pada 29 Agustus 2021

42 Profil Negara Turki melalui website Konsulat Jendral Republik Istambul Turki, Depertemen Luar Negri RI melalui link https://kemlu.go.id/istanbul/id/pages/profil_negara_turki/3232/etc-menu diakses pada 29 Agustus 2021 
dengan Negara-negara Anggota Uni Eropa lainnya yang berpenduduk Non Muslim. ${ }^{43}$

\section{Kesimpulan}

Keinginan Turki untuk dapat bergabung dengan Uni Eropa sudah terlihat sejak puluhan tahun lalu, ketika Turki secara formal mengajukan permohonannya menjadi anggota tetap pada tahun 1987. Memiliki sejarah pernah dalam penguasaan Bangsa Romawi selama 14 abad sebelum dikuasai Kekaisaran Ottoman di masa lalu dan secara geografis berada di Eropa dan Asia tak serta merta menjadikan Turki diterima dengan mudah menjadi anggota Uni Eropa. Sebaliknya, berbagai upaya yang dilakukan selama lebih dari tiga dekade justru berujung dengan kegagalan, bagi Uni Eropa Turki masih saja tetap belum memenuhi syarat. Selalu ada saja yang menjadi hambatan mulai dari isu HAM, ekonomi, politik dan yang tak pernah disebutkan terang-terangan adalah adanya Islamphobia dari negara-negara anggota. Situasi ini diperburuk dengan kebijakan luar negeri Turki melalui Presiden Recep Tayyib Erdogan yang memimpin Turki sejak 2002 kerap berseberangan dengan negara-negara kuat anggota Uni Eropa terutama Jerman dan Prancis yang merupakan negara dominan dalam setiap pengambilan keputusan di Uni Eropa.

\section{Bibliografi}

Bassam, Tibb, Islam between Culture and Politics. New York: Palgrave Publishers Ltd, 1997

BBC News. "Diperangi Erdogan, tak diakui di Suriah, Siapa sesungguhnya bangsa Kurdi?”. https://www.bbc.com/indonesia/dunia-50068256

CNBC Indonesia, "Erdogan Siap Perang Lawan Yunani, Ini Penyebabnya." https://www.cnbcindonesia.com/news/20200831091027-4183166/erdogan-siap-perang-lawan-yunani-ini-penyebabnya31 Agustus 2020

\footnotetext{
43 Rep: Ratna Ajeng Tejomukti/ Red: Nashih Nashrulla, Lima Fakta di Balik Tingginya Populasi Muslim di Eropa melalui link https://republika.co.id/berita//qnlsz9320/lima-fakta-di-balik-tingginya-populasimuslim-di-eropa diaskes pada 29 Agustus 2021
} 
Conrad Hackett. "5 facts about the Muslim population in Europe." https://www.pewresearch.org/fact-tank/2017/11/29/5-facts-aboutthe-muslim-population-in-europe/

Erich, Hochleitner. "The Political Criteria of Copenhagen and their application to Turkey, Working Paper." Austrian Institute for European Security Policy August, 2005

European Neigbourhood Policy and Enlargement Negotiations. "Negotiations Turkey" European commision website. https://ec.europa.eu/neighbourhood-enlargement/enlargementpolicy/negotiations-status/turkey_en

Faidah, Rahim. "Clash of Civilisations: Hambatan Aksesi Turki ke Uni Eropa." Global\& Policy 1, no. 2 (2013): 214-227. doi: https://core.ac.uk/download/pdf/19892242.pdf

History of Turkey-EU Relations. https://www.ab.gov.tr/siteimages/birimler/kpb/chronology-_en-_1959_ocak2020.pdf 1959 - 2019

Huntington, Samuel P. The Clash of Civilization and Remarking of World Order, New York: Simon \& Schuster, 1996

Ilham, Ozturk, dan Kamil Sertoglu. "Turkey and European Union Relations: Concept of the Custom Union." Pakistan Horizon 56, no. 3 (2003): 1-13 doi:https://mpra.ub.uni-muenchen.de/333/1/MPRA_paper_333.pdf

Johanna, Können. “Cultural Diplomacy and the Debate on Turkey's Accession to the EU." http://www.culturaldiplomacy.org/pdf/case-studies/cddebate.pdf

Konsulat Jenderal Republik Indonesia Istanbul Turki," Profile Turki”. https://kemlu.go.id/istanbul/id/pages/profil_negara_turki/3232/etcmenu

Koran Tempo, Mimpi Turki di Eropa. https://koran.tempo.co/read/internasional/29320/mimpi-turki-dieropa Edisi 16 December 2004

Lenczowski, George. Timur Tengah di kancah Dunia. Bandung: Sinarbaru Algesindo, 1993.

Maria Rita Hasugian. "Eks Menteri Turki dirikan Partai untuk Hadang Erdogan.” Tempo.com. https://dunia.tempo.co/read/1028098/eks-menteri-turki- 
Saragih, H. M. et. al: Rekam Jejak Kegagalan Turki Menjadi Anggota Uni Eropa| 229

dirikan-partai-untuk-hadang-erdogan/full\&view=ok

Marcinkowski, Christoph. "European Union with Turkey: The Possible Impact of Turkey's Membership on the European Union." ProQuest Journal I (2010): 537

Muhammad Idris, "Erdogan, Hagia Sophia, dan Krisis Ekonomi Turki", https://money.kompas.com/read/2020/07/25/115019726/erdogan-hagiasophia-dan-krisis-ekonomi-turki?page=all25 Juli 2020.

Oner, Selcen. "Turkey's Membership to the EU in Terms of 'Clash of Civilization." Journal of Interdisciplinary Economics (2009) doi:https://doi.org/10.1177/02601079X09002000304,

Ratna, Ajeng Tejomukti, Nashih Nashrullah. “13 Negara Eropa yang Muslimnya Diprediksi Jadi Mayoritas". Republika.co.id. Diakses 17 Februari 2021.https://www.republika.co.id/berita/qon91c320/13-negara-eropayang-muslimnya-diprediksi-jadi-mayoritas

Ratna, Ajeng Tejomukti, Nashih Nashrulla. "Lima Fakta di Balik Tingginya Populasi Muslim di Eropa". Republika.co.id. Diakses 28 Januari 2021.https://republika.co.id/berita//qnlsz9320/lima-fakta-di-baliktingginya-populasi-muslim-di-eropa

Rehiya, Sebayang. "Ekonomi Negeri Erdogan Tumbang, Turki di Ambang Resesi”. CNBC Indonesia. https://www.cnbcindonesia.com/market/20200813084935-17179449/ekonomi-negeri-erdogan-tumbang-turki-di-ambang-resesi

Riza Sihbudi, M., Islam, Dunia Arab, Iran: Barat Timur Tengah. Bandung: Mizan 1991

Roy, Oliver. The Failure of Political Islam. Terjemahan Carol Volk. Cambridge, MA: $\quad$ Harvard University Press, 1994

Sara De Luca, Albrecht Glitz, dan Francesc Ortega. Immigration in Europe: Trends, Policies, and Empirical Evidence. IZA, 2013

Sari, Andina, Bachri, Saiful. "Upaya Pemerintah Turki Dalam Mengatasi Gerakan Separatisme Suku Kurdi Tahun 1984-2007." http://download.garuda.ristekdikti.go.id/article.php?article=1413075\& $\mathrm{val}=4059$ 
Setyowati, Agnes. Ideologi Islam, Barat, dan Amerika Potret Sejarah Global Kepentingan Dalam Pertarungan Diskursif. Yogyakarta: Suluh Media, 2017

The World Bank in Tureky Overview (release resmi). https://www.worldbank.org/en/country/turkey/overview

Triesanto, Romulo Simanjuntak, Dafri, Agussalim. "Sikap Negara-Negara Anggota Uni Eropa Dalam Menangani Krisis Yunani (Studi Kasus: Sikap Jerman, Perancis dan Inggris)." http://www.antaranews.com

Turkey in brief (situs resmi Turkey yang dikutip oleh Deplu RI). https://www.nationsonline.org/oneworld/turkey.htm

Turkey trade and economic update - https://www.mfat.govt.nz/kr/trade/mfatmarket-reports/market-reports-middle-east/turkey-trade-andeconomic-update-july-2021/

Wardana, Adhi. "Upaya Pemerintah Turki Untuk Bergabung Dengan Uni Eropa." Jurnal Global Political Studies. doi:https://ojs.unikom.ac.id/index.php/gps/article/download/2015/13 $56 /$ 